\title{
Shifting Shores and Shoring Shifts- How Can Beach Managers Lead Transformative Change? A Study on Challenges and Opportunities for Ecosystem-Based Management
}

\author{
Marina Ribeiro Corrêa ${ }^{1}$ \\ Institute of Energy and Environment, University of São Paulo, Brazil, and Department \\ of Social Sciences, Leibniz Centre for Tropical Marine Research, Bremen, Germany \\ Luciana Yokoyama Xavier \\ Oceanographic Institute, University of São Paulo, Brazil, and Department of Social \\ Sciences, Leibniz Centre for Tropical Marine Research, Bremen, Germany \\ Eike Holzkämper \\ Social-Ecological Systems Analysis Working Group, Social Science Department, \\ Leibniz Centre for Tropical Marine Research, Bremen, Germany \\ Mariana Martins de Andrade \\ Oceanographic Institute, University of São Paulo, Brazil \\ Alexander Turra \\ Oceanographic Institute, University of São Paulo, Brazil \\ Marion Glaser \\ Social-Ecological Systems Analysis Working Group, Social Science Department, \\ Leibniz Centre for Tropical Marine Research, Bremen, Germany
}

\section{Abstract}

Beaches provide a range of ecosystem services (ES). They are increasingly impacted by climate change, among other stressors. Ecosystem-based management (EBM) is an approach to cope with a changing environment and ensure long-term ES provision. Local managers may facilitate beach EBM implementation by integrating it into existing governance systems. However, their role in EBM implementation needs clarifying. This paper assesses local government beach managers' perceptions and visions of improvement of the beach ES governance network to face a changing environment. We present a structural analysis of data from the northern coast

1 Corresponding author: marina.ribeiro.correa@usp.br. 
of São Paulo state (Brazil) and discuss opportunities and challenges for a regional EBM implementation. Our results point to the local beach managers as potential leaders of transformations towards sustainability.

Keywords: ecosystem approach, governance network, Net-Map, sandy beaches, social network analysis.

\section{Context}

Beaches provide a range of benefits for human well-being (Sardá \& Azcárate, 2018) but human-induced impacts (e.g., climate change, human activities, pollution, engineering structures) transform beach-related ecological and social processes, threatening their sustainability (McLachlan \& Defeo, 2018). To cope with the changing environment, beach management requires effective, collaborative, and inclusive governance structures (Sardá et al., 2015). Analyzing the web of social relations (i.e., social networks) that constitute the governance system can help to identify how to improve it (Bodin, 2017; Bodin \& Crona, 2009).

Environmental governance can be seen as a system of "actor-networks at all levels of human society (from local to global) that are set up to steer societies towards ... adapting to global and local environmental change ... within the normative context of sustainable development" (Biermann et al., 2010, p. 279). A governance network is a set of actors, or "nodes," with distinct attributes (e.g., perceptions, information, power), which may be connected to one another (or not) by pathways through which interactions take place, known as "ties" (Cohen et al., 2012). In addition to the multi-actor structure, the analysis of environmental governance networks needs to consider administrative borders and how administrative units fit (or don't) with ecosystem dynamics (Bodin, 2017; Carlsson \& Sandström, 2007). Environmental governance studies often describe the social processes that promote governance networks for sustainability, but with less regard to ecosystem functioning (see Bodin, 2017). The advance of beach governance should recognize both ecosystems functioning and the involved social networks.

Ecosystem-based management $(\mathrm{EBM})^{2}$ responds to environmental change (e.g., climate change) to steer multilevel social-ecological systems ${ }^{3}$ dynamics toward sustainability (Chapin III et al., 2009; McLeod \& Leslie, 2009; Sardá et al., 2015; Wamsler et al., 2014); a desirable approach for beach management

\footnotetext{
2 Although EBM and ecosystem approach are not synonymous concepts, they share the same principles and when applied in practice they often lead to similar outcomes (Kirkfeldt, 2019). In order to better discuss the results of the present research, these concepts were used synonymously.

3 Socioecological systems: coupled, coevolving, and dynamic human-nature systems, with reciprocal and interdependent feedback (e.g., McLeod \& Leslie, 2009). We use the terms socioecological and social-ecological (e.g., publications by Carl Folke and colleagues of the Stockholm Resilience Centre) synonymously.
} 
(Corrêa et al., in press; Sardá \& Azcárate, 2018; Sardá et al., 2015). EBM is rooted in the connections between human well-being and ecosystem functioning (McLeod \& Leslie, 2009; Sardá et al., 2015). The ecosystem services (ES) concept (i.e., ecosystem contributions that provide human well-being) operationalizes this idea (Granek et al., 2010; McLeod \& Leslie, 2009; O’Higgins et al., 2020; Sardá et al., 2015; Tallis et al., 2010) with a focus on conserving ecosystem functioning to ensure long-term ES provision (Chapin III et al., 2009; O'Higgins et al., 2020; Sardá et al., 2015).

EBM promotes sustainability by eliciting longer term planning in line with ecosystem dynamics (Chapin III et al., 2009; McLeod \& Leslie, 2009). It embraces the "adaptive capacity" concept-that is, the ability of humans to manage a changing environment, including their capacity to adjust social networks (Adger, 2003; Chapin III et al., 2009; O'Higgins et al., 2020). Good governance is one of the preconditions for EBM implementation (O'Higgins et al., 2020) and includes building and managing ES governance networks of holistically understood socialecological dynamics (Imperial, 1999).

However, EBM implementation for beaches is incipient, at best, and understudied (Sardá \& Azcárate, 2018). To promote the transformation toward innovative and sustainable forms of environmental governance such as EBM for beaches, critical contextual opportunities and barriers (e.g., stakeholders, networks) need to be identified (Aswani et al., 2012; Christie et al., 2009; Kelly et al., 2018). This paper investigates two barriers to EBM implementation for beaches. Both are related to governance processes and structures.

The first barrier is to overcome current undesirable governance structures. EBM envisages the engagement of a diverse set of stakeholders (Bodin et al., 2017; McLeod \& Leslie, 2009). Existing governance systems, however, can hamper innovative EBM implementation (Glaser et al., 2018; O'Higgins et al., 2020; Tallis et al., 2010): a variety of context-specific features may be obstructive (e.g., governance networks) (Bodin et al., 2017; Smythe et al., 2014; Wamsler et al., 2014). Beach management is historically characterized by low stakeholder involvement, fragmented governance, and little regard for ecological features (Sardá et al., 2015; Williams \& Micallef, 2009). These issues manifest in undesirable resilient structures (Glaser et al., 2018) that reduce management's capacity to redirect toward sustainability-enhancing management systems such as EBM (Arkema et al., 2006; Leslie et al., 2015). Beach management and governance need to innovate structurally and procedurally to ensure the long-term provision of beach ecosystem services (BES) (Sardá et al., 2015).

The second barrier is to fit governance to multilevel ecosystem dynamics. EBM implementation on any spatial level depends heavily on the local governance context (e.g., social participation, interinstitutional collaboration) (Christie et al., 2009; 
Leslie et al., 2015). Beach management usually focuses on the local level— the beach or the municipality (McLachlan \& Defeo, 2018; Williams \& Micallef, 2009)—but deals with multilevel biophysical processes and impacts (McLachlan \& Defeo, 2018). To implement EBM, beach management must operate in a multilevel governance system that addresses all social-ecological system levels that affect beaches, including watersheds (Corrêa et al., in press; Sardá et al., 2015), and consider administrative levels beyond the local to promote beach sustainability (Sardá et al., 2015).

To tackle these EBM implementation barriers, a central actor can orchestrate collaboration among multiple stakeholders and administrative levels (Bodin et al., 2017). Local government officials are potential leaders for EBM implementation (Sandström et al., 2015). By "weaving"-that is, actively developing a collaborative social network among different social groups-they can promote ecosystem fit and break undesirable resilient features (Carlsson \& Sandström, 2007; Sandström et al., 2015). However, more information is needed on how local government actors may be able to weave networks (e.g., ES governance networks) to support a transformation towards EBM (Sandström et al., 2015).

Network weaving is shaped by network actors and by their perceptions (Glaser et al., 2018; Holzkämper, 2017). According to Beyerl et al. (2016, p. 4), perception is "the subjective way people experience, think about and understand someone or something." Understanding what local government actors perceive as the changes needed in beach governance networks to safeguard long-term ES is part of the assessment of these central actors' ability to cope with social-ecological change (i.e., perceived adaptive capacity, Grothmann \& Patt, 2005). Local beach management actors' perceptions of the network transformations necessary for dealing with a changing environment, therefore, might be a critical "bottleneck" for EBM implementation. We target two questions: (i) As possible leaders of change, how do local government managers perceive needed long-term improvements in their BES governance networks under conditions of ecosystem change? (ii) Can their perceptions promote a fit between the governance structure and beach dynamics?

We adopt an inductive approach using the Net-Map method (Schiffer \& Hauck, 2010) and social network analysis (SNA) to investigate the perceptions of municipal beach managers of four municipalities of the northern coast of São Paulo state, Brazil, a region in need of local coastal leadership to cope with ongoing changes (Simóes et al., 2017). ${ }^{4}$ SNA is a tool to characterize relationships among actors (Freeman, 2004) and has been used to better understand environmental governance structures and EBM implementation processes (Bodin et al., 2017; Smythe et al., 2014). Our analysis centers on the two identified barriers to EBM implementation (undesirable resilient structures and governance misfit). We identify perception patterns and discuss their implications for beach management as well as opportunities

4 In Brazil, the municipal level is the lowest administrative level, hereafter described as "local". 
and challenges for EBM implementation. The article concludes by reflecting on the role of local beach managers as leaders of change towards sustainable system dynamics in Brazil and other coastal regions across the world, especially those with decentralized management.

\section{Methods}

\section{Study site}

Brazil has one of the longest coastlines worldwide, where beaches provide essential ES subjected to complex, cumulative threats, including climate change (Amaral et al., 2016; Ministério do Meio Ambiente, 2018; Xavier et al., in press). Implementing EBM in Brazilian beach management has the potential to guide, adapt, and improve current structures and processes in a holistic manner (Xavier et al., in press). Beach management in Brazil also faces challenges for EBM implementation including low stakeholder involvement, fragmented governance, and lack of multilevel governance processes (Corrêa et al., in press; Xavier et al., in press).

Brazilian beach management occurs at the municipal level but is regulated by higher level legislation (Xavier et al., in press). Currently, the federal government is transferring management rights and responsibilities to municipalities, in a decentralization process to ensure the sustainable use of the coastal zone and more participatory beach management (Scherer et al., 2020; Xavier et al., in press). This is an opportunity for local governments to become central actors in beach management with increased autonomy and power (Scherer et al., 2020). In line with municipalization, the National Plan of Climate Change Adaptation encourages the inclusion of ES-based strategies in municipal policies and beach management (Ministério do Meio Ambiente, 2018). This creates a new scope for local government actors to weave networks (e.g., ES governance networks) to support EBM implementation.

The north coast of São Paulo state (Litoral Norte Paulista-LNP) is a compelling site to study the improvement of beach governance networks to implement EBM. The LNP urbanization process is mainly related to tourism and leisure (Santos \& Turra, 2017): both depend on beach quality and long-term beach ES (BES) provision. The four LNP municipalities (São Sebastiáo, Ubatuba, Ilhabela, and Caraguatatuba) are committed to or in the process of assuming the management of their beaches. They share resources and face common social-ecological vulnerabilities, such as climate change-induced impacts like increased coastal erosion (Santos \& Turra, 2017; Simóes et al., 2017). At the regional level, the municipalities are integrated into environmental decision-making bodies (i.e., council bodies-composed of multiple sectors and governance levels). These discuss and implement a common 
management strategy for the regional coastal, watershed, and protected areas management (Santos \& Turra, 2017) but they do not discuss beach management; which is implemented by the municipalities. ${ }^{5}$ Local municipalities still need to establish long-term and inclusive strategic planning and local leadership to cope with the changing environment (Simões et al., 2017).

\section{Data collection}

Net-Map (Schiffer \& Hauck, 2010) is a group dynamic tool for collecting data on social network perceptions. As actors achieve a greater understanding of their networks, they can identify what network changes are needed for specific aims, such as EBM implementation. We applied an adapted Net-Map method developed by Glaser et al. (2018) to visualize municipal beach managers' perceptions of current relations among those dealing with BES governance in the LNP region, and their ideas for needed improvements in social network structure and functioning to ensure long-term BES provision under a changing environment.

Long-term change in the beach system centrally includes the coastal squeeze phenomenon, caused by climate change and uncontrolled urban growth, resulting in beaches eroding and disappearing (McLachlan \& Defeo, 2018). These are globally induced impacts that demand local and regional management (McLachlan \& Defeo, 2018). Beach managers are government officers: they are concerned with civil society safety, environmental protection, public infrastructure, and the development of areas close to beaches (Moser \& Tribbia, 2006). In Brazil, beach management is often performed by different municipal government offices. In each of the four LNP municipalities, we approached the three municipal government offices that were most involved in beach sustainability (for further information on Net-Map participants, see Appendix I).

We conducted 11 Net-Map sessions (each with 3-5 beach managers): three in Caraguatatuba (C1, C2, C3), Ubatuba (U1, U2, U3), and São Sebastião (SS1, SS2, SS3), and two at Ilhabela (I1, I2), yielding 22 networks (11 representing the current scenario and 11 visualizing a desirable future). Sessions were voice-recorded and filmed. This research was approved by the Brazilian Ethics Committee (Plataforma Brasil: 3.337.019), and all participants signed an informed consent form. The sessions followed a six-step procedure (Figure 1).

5 This information comes from two workshops carried out with the main LNP Council bodies to discuss beach management. The workshops were held by a bigger research project that includes the present research. The data still is unpublished. 
1

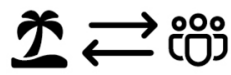

1. Establish common understandings Managers discussed how beach biophysical processes relate to social welfare and provide Ecosystem Services. They reflected on how the benefits provided are affected by coastal benefits provided are affected by coastal erosion processes. This discussion led to a shared understanding of the concepts:

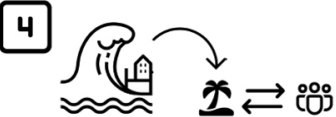

4. Discuss change: Managers discussed how increased erosion due to climate change can affect BES in the future, and what are the necessary measures to ensure a long-term BES provision.

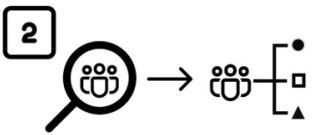

2. Identify and classify actors: Managers dentified who is currently involved with the maintenance of BES considering the current coastal erosion scenario. Actors were classifie as: public sector, civil society, private sector, research organizations, and council bodies. research organizations, and council administrative level they act on.

\section{5}

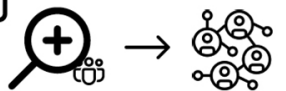

5. Pinpoint who acts: Managers identified which actors should be included in the current governance network and which interactions would need to be improved (including conflic that need to be changed into collaborative links). The desired BES governance network (DGN) was built.
3

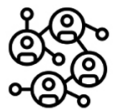

3. Identify links: Managers identified existing governance interactions among actors: with this data, the current perceived BES governance network (CPGN) was built. Based on Schiffer and Hauck (2010), interactions were categorized as either collaborative

(information, support, or money flow) or conflictive relations.
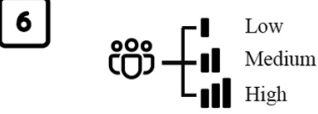

6. Identify actor power and expertise: Manager classified all identified actors in terms of: i) Perceived power (i.e. reputational influence) to promote network transformation; ii) Perceived expertise (i.e. technical and empirical knowledge) to guide the transformation, ensuring the longterm provision of $\mathrm{BES}$.

Figure 1. The six-step procedure adopted in the Net-Map sessions performed in this study.

Source: Authors' summary of process.

\section{Data analysis}

We digitized the network data for further computerized visual and mathematical analysis, including the application of SNA metrics on the resulting governance network (detailed information on data treatment is provided in Appendix II). We restricted our analysis to collaborative relations since not all informants were comfortable discussing conflicts. With this analysis, we identified the envisioned changes in the BES governance network. We analyzed the perceived BES governance networks and how positive change was envisioned (i.e., transformations in the governance network perceived as necessary to ensure the provision of BES). Using UCINET 6 (Borgatti et al., 2002), we examined current perceived governance networks (CPGN) and desired governance networks (DGN) for differences and similarities. We investigated how interactions between administrative levels in the DGN were perceived. The following paragraphs outline the network metrics on two barriers for EBM: current governance structures and governance fit with ecosystem dynamics.

\section{Barrier 1: Overcome current undesirable governance structures}

Actor diversity promotes collaborative governance and EBM implementation (Arkema et al., 2006; Bodin et al., 2017; McLeod \& Leslie, 2009), while the links among actor categories enact the exchanges of knowledge and resources needed to achieve collaborative governance for EBM implementation (Bodin et al., 2017; Smythe et al., 2014). Governance network structure and composition can indicate 
the ability of actors to overcome challenges for EBM implementation (Bodin et al., 2017). Network metrics were chosen to assess the perceived diversity of actors and links among actor categories (Table 1).

Table 1. Network metrics on actor diversity, links among actor categories, and how these differ between CPGN and DGN.

\begin{tabular}{|c|c|c|}
\hline & Network metric & Description \\
\hline \multirow{2}{*}{$\begin{array}{l}\text { Actor } \\
\text { diversity } \\
\text { and } \\
\text { influence }\end{array}$} & Network composition & $\begin{array}{l}\text { "Actor categories" are defined in step } 2 \text { of Figure } 1 \\
\text { We determined the proportion of each actor category } \\
\text { in each network. }\end{array}$ \\
\hline & $\begin{array}{l}\text { Perceived influence } \\
\text { (i.e., power and expertise) } \\
\text { of each actor category }\end{array}$ & $\begin{array}{l}\text { For both "perceived power" and "perceived } \\
\text { expertise," the most frequently attributed strength } \\
\text { level ("Low," "Medium," or "High") was used for each } \\
\text { actor category. }\end{array}$ \\
\hline \multirow[t]{3}{*}{$\begin{array}{l}\text { Links } \\
\text { among } \\
\text { actor } \\
\text { categories }\end{array}$} & $\begin{array}{l}\text { Homophily/heterophily } \\
\text { (Bodin, 2017) }\end{array}$ & $\begin{array}{l}\text { The degree of connectivity across actor categories. } \\
\text { Homophily/heterophily varies between }-1 \text { and } 1 \text {, } \\
\text { where }-1 \text { represents complete homophily (connection } \\
\text { only between actors of the same category) and } \\
1 \text { complete heterophily (connection only between } \\
\text { actors of different categories). }\end{array}$ \\
\hline & $\begin{array}{l}\text { Network fragmentation } \\
\text { (Coleman, 1990; } \\
\text { Holzkämper, 2017) }\end{array}$ & $\begin{array}{l}\text { The extent to which actors have access to } \\
\text { information and knowledge, measured by the fraction } \\
\text { of node pairs that are (un)reachable in a network. } \\
\text { Fragmentation is } 0 \text { when all nodes are connected } \\
\text { and } 1 \text { when all nodes are isolated: networks are } \\
\text { fragmented (scores } 1-0.7 \text { ), balanced (scores } 0.6-0.4 \text { ), } \\
\text { or connected (scores } 0.3-0 \text { ). }\end{array}$ \\
\hline & $\begin{array}{l}\text { Network centralization } \\
\text { (Carlsson \& Sandström, } \\
\text { 2007; Holzkämper, 2017; } \\
\text { Sørensen \& Torfing, 2016) }\end{array}$ & $\begin{array}{l}\text { The extent to which network relations and power } \\
\text { are centralized with one or more key/focal actors, } \\
\text { showing whether different degrees of fragmentation } \\
\text { are associated with a high level of cooperation } \\
\text { (low fragmentation) or with hierarchical coordination } \\
\text { (high fragmentation). Distinguishes between } \\
\text { centralized (scores } 1-0.7 \text { ), decentralized (scores } \\
0.6-0.4 \text { ) and distributed (scores } 0.3-0 \text { ) networks. }\end{array}$ \\
\hline
\end{tabular}

Note: CPGN = current perceived governance network; DGN = desired governance network.

Source: Authors' summary. See also citations throughout table.

We compared CPGN and DGN, investigating differences in desired change patterns using the concepts of "collaborative heterogeneity" and "coordinated heterogeneity" (Bodin et al., 2017) for the network structure considered as needed for effective EBM implementation (Table 2). 
Table 2. Change patterns examined to analyze beach managers' perceptions of needed governance network changes to ensure BES. In each type of network change, fragmentation decreases or stays constant (as "connected" or "balanced"), envisioning increased collaboration among actors. Change patterns differ in with whom (homo-/heterophily) and how (self-organized/coordinated) actors should ideally connect.

\begin{tabular}{|l|l|l|}
\hline Change pattern & Network indicators & Type of envisioned network change \\
\hline $\begin{array}{l}\text { Self-organized } \\
\text { heterophily }\end{array}$ & $\begin{array}{l}\text { - Increase in heterophily; } \\
\text { - Centralization maintained } \\
\text { as "decentralized." }\end{array}$ & $\begin{array}{l}\text { Increased cooperation among actors } \\
\text { of different categories is promoted in } \\
\text { a collaborative environment. }\end{array}$ \\
\hline $\begin{array}{l}\text { Coordinated } \\
\text { heterophily }\end{array}$ & $\begin{array}{l}\text { - Increase in heterophily; } \\
\text { - Centralization increased } \\
\text { and changed from } \\
\text { "decentralized" to } \\
\text { "centralized." }\end{array}$ & $\begin{array}{l}\text { A central actor (the Net-Map respondent) } \\
\text { promotes increased collaboration through } \\
\text { hierarchical coordination connecting actors } \\
\text { of different categories. }\end{array}$ \\
\hline $\begin{array}{l}\text { Self-organized } \\
\text { homophily }\end{array}$ & $\begin{array}{l}\text { - Increase in homophily; } \\
\text { - Centralization maintained } \\
\text { as "decentralized." }\end{array}$ & $\begin{array}{l}\text { Increased cooperation among actors } \\
\text { of the same category is promoted in } \\
\text { a collaborative environment. }\end{array}$ \\
\hline $\begin{array}{l}\text { Coordinated } \\
\text { homophily }\end{array}$ & $\begin{array}{l}\text { Increase in heterophily; } \\
\text { Centralization increased } \\
\text { and changed from } \\
\text { "decentralized" to } \\
\text { "centralized." }\end{array}$ & $\begin{array}{l}\text { Hierarchical coordination promotes } \\
\text { connection among actors of the same } \\
\text { category. A central actor (the Net-Map } \\
\text { respondent) links to "subgroups" of actors } \\
\text { of mostly the same category, promoting } \\
\text { a collaborative process. }\end{array}$ \\
\hline
\end{tabular}

Note: BES = beach ecosystem services.

Source: Authors' summary, after Bodin et al. (2017).

\section{Barrier 2: Fit governance to multilevel ecosystem dynamics}

EBM implementation aims to improve the fit between governance systems and ecosystems by collaboration across administrative units and levels (Smythe et al., 2014). Two additional aspects were analyzed to assess opportunities and challenges for multilevel collaboration:

1. How the participants perceived the connections of their local governance networks to other municipalities. This was indicated by their perceptions of (1) the presence of actors from other LNP municipalities; and (2) the presence of actors from higher administrative levels.

2. How the participants perceived the participation of different administrative levels in governance network transformation. The perceived expertise and power for each actor category was analyzed, focusing on the different administrative levels. 


\section{Results}

\section{Barrier 1: Overcome current governance structures}

\section{Network composition}

LPN beach managers identified all five actor categories (research organizations, council bodies, private sector, civil society, and public sector) (Figure 2). All municipal offices named actors from the public sector, civil society, and the private sector, while four municipal offices (SS2, SS3, I1, and I2) did not include council bodies and/or research organizations in their CPGNs or DGNs. The proportion of actors from the public sector reached 60 percent or more in almost all CPGNs, outweighing all other actor categories (Figure 2). There were more actors in almost all DGNs (except for SS3) than in CPGNs.

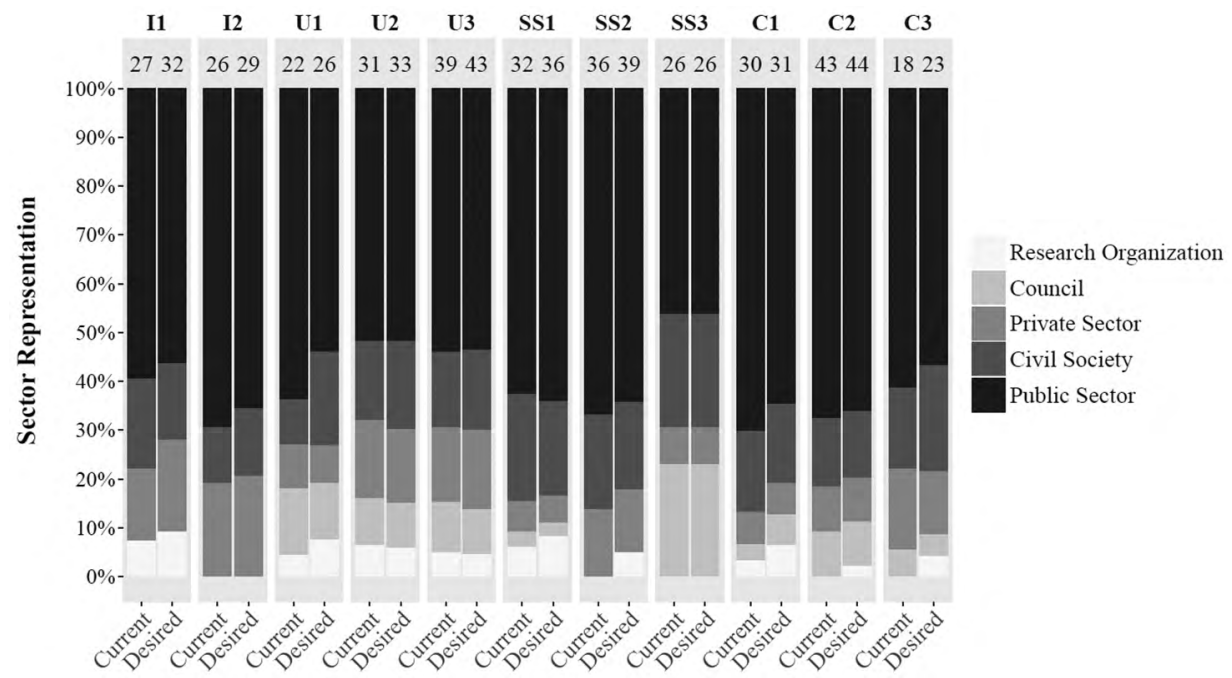

Figure 2. Overview of perceived governance network composition (actor categories: research organization, council, private sector, civil society, public sector).

Note: Y-axis indicates percent of actor category. X-axis indicates the governance network (current/desired) for each municipal office (I-Ilhabela; U-Ubatuba; SS-São Sebastião; C-Caraguatatuba). The number above the bar indicates how many actors were named in the network.

Source: Authors' summary.

Actor category representation differed between CPGNs and DGNs (Figure 3). Public sector representation was lower in most DGNs, in all municipalities. Civil society representation was constant or higher in most DGNs, and at least one municipal office per municipality pointed to the need of increasing it. The representation of research organizations increased in most DGNs in all studied municipalities. Qualitative data supported this: research organizations were generally considered important for capacitation and knowledge exchange (Figure 3). 
Representation difference

(desired network - current network)

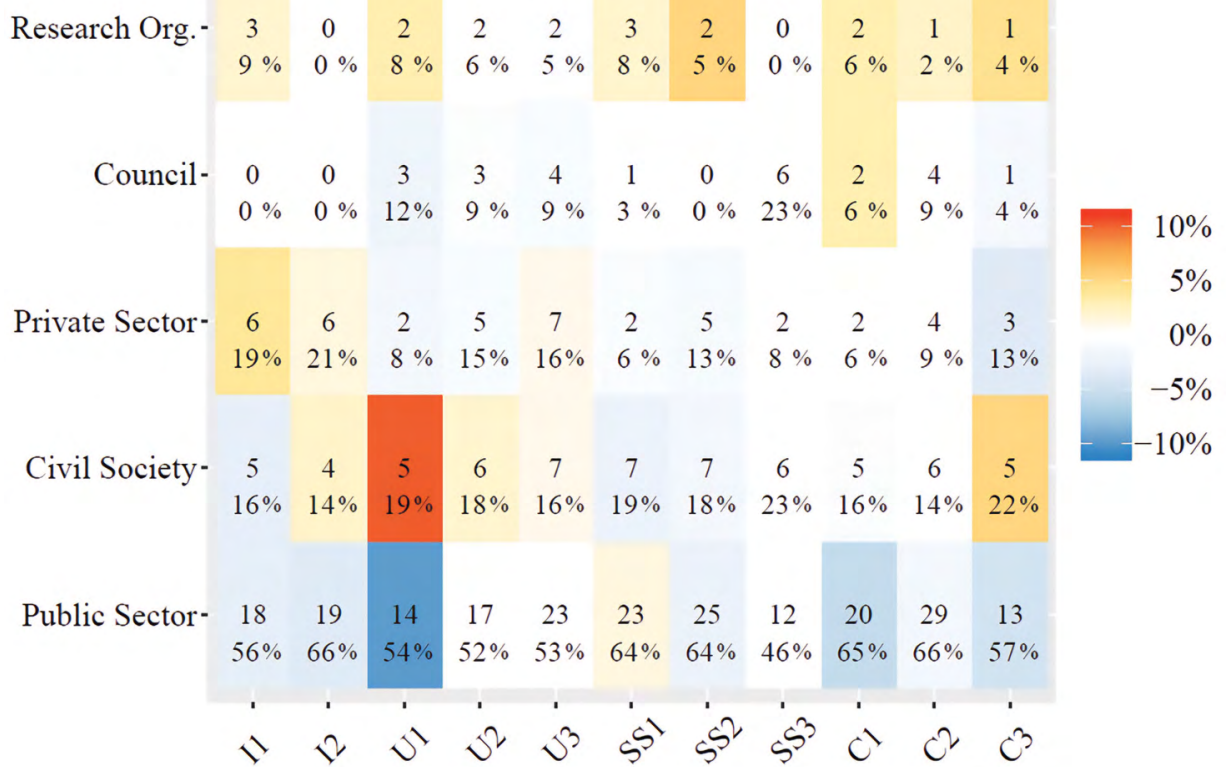

Figure 3. Actor categories' representation (in percent) in current CPGNs and DGNs.

Note: Y-axis shows actor categories (research organization, council, private sector, civil society, public sector). X-axis represents the municipal offices (I-llhabela; U-Ubatuba; SS-São Sebastião; C-Caraguatatuba). Color scale indicates the difference (percent) between DGN and CPGN by category. The numbers inside the boxes indicate the absolute number (top) and representation percent (bottom) by category in each DNG.

Source: Authors' summary.

Perceptions of expertise and power to guide transformation varied by actor category (Table 3).

Table 3. The perceived expertise and power of actor categories to promote and guide the desired changes in the governance networks towards long-term BES provision.

\begin{tabular}{|l|c|c|c|c|c|} 
& $\begin{array}{c}\text { Research } \\
\text { organization }\end{array}$ & $\begin{array}{c}\text { Council } \\
\text { bodies }\end{array}$ & $\begin{array}{c}\text { Private } \\
\text { sector }\end{array}$ & Civil society & Public sector \\
\hline $\begin{array}{l}\text { Perceived } \\
\text { expertise }\end{array}$ & High & High & Low & Low & Medium \\
\hline $\begin{array}{l}\text { Perceived } \\
\text { power }\end{array}$ & Low & High & High & Low & High \\
\hline
\end{tabular}

Note: $B E S=$ beach ecosystem services.

Source: Authors' summary. 


\section{Linkages among actor categories}

Most envisioned network changes indicated self-organized processes. One DGN (SS3) did not envision any change. All envisioned transformations were toward decreased fragmentation. Half of the DGNs had homophily tendency and half had heterophily tendency. Two DGNs (SS1 and U3) envisioned less fragmentation by increasing the centralization of municipal offices: SS1 with a heterophily tendency and U3 with a homophily tendency (Figure 4).

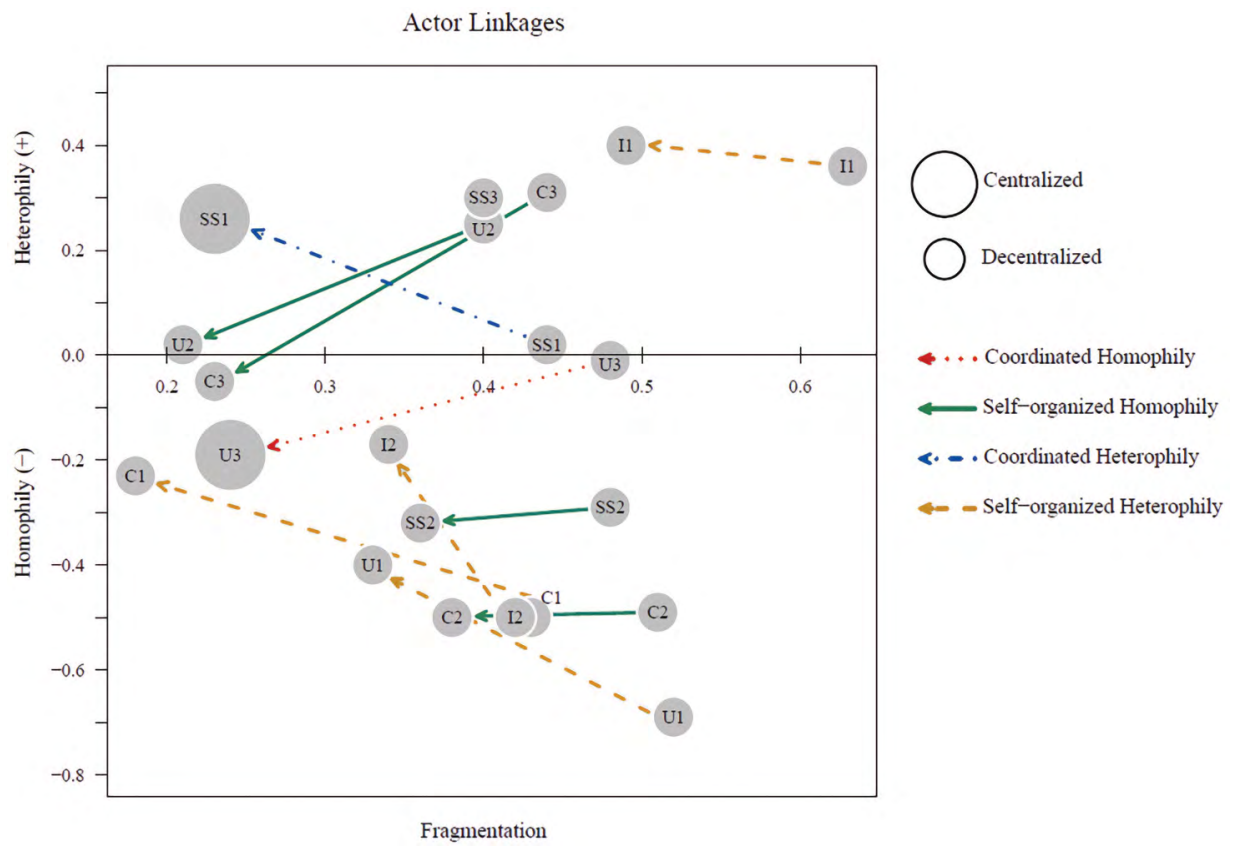

Figure 4. Governance networks of study municipalities (circles: I-Ilhabela; U-Ubatuba; SS-São Sebastião; C-Caraguatatuba).

Note: Circle size represents the centralization metric. Arrows point to the desired ES governance network configuration. Y-axis shows homophily/heterophily; X-axis fragmentation. Four patterns of envisioned change from CPGN to DGN to ensure BES: coordinated homophily; self-organized homophily; coordinated heterophily; self-organized heterophily.

Source: Authors' summary.

\section{Barrier 2: Fit governance to multilevel ecosystem dynamics}

In all the municipalities, at least one municipal office named actors from higher administrative levels as endowed with high expertise and power (Table 4). Each Net-Map group only perceived their own municipality as a network actor at the local level: stakeholders from other municipalities were not mentioned. The beach managers perceived municipal actors as having low expertise, while regional, state, and federal level actors were seen as having high expertise. Although all administrative 
levels were associated with a high level of power to promote desired transformations in the governance network, the federal and state governments were generally seen as exerting their relatively high power through formal command, without spaces for participation in decision-making (e.g., "as a municipality, we cannot change how it works").

Table 4. Perceived expertise and power of administrative actors at different levels for guiding governance network changes towards long-term BES provision.

\begin{tabular}{|l|l|l|l|l|}
\hline $\begin{array}{l}\text { Actors } \\
\text { perceived by all } \\
\text { municipalities }\end{array}$ & Municipal & Regional & State & Federal \\
\hline $\begin{array}{l}\text { Perceived } \\
\text { expertise }\end{array}$ & Low & $\begin{array}{l}\text { Nongovernmental } \\
\text { organization who } \\
\text { operates regionally } \\
(\text { civil society actor) } \\
(n=8)\end{array}$ & $\begin{array}{l}\text { State environmental } \\
\text { surveillance agency } \\
(n=8), \text { State Civil } \\
\text { Defense }(n=5), \text { State } \\
\text { Public Prosecution } \\
\text { Office }(n=7)\end{array}$ & $\begin{array}{l}\text { Navy }(n=8), \\
\text { governmental } \\
\text { actor with } \\
\text { authority on beach } \\
\text { territories }(n=5)\end{array}$ \\
\hline Perceived power & High & High & High & High \\
\hline
\end{tabular}

Note: BES = beach ecosystem services.

Source: Authors' summary.

\section{Discussion}

We mapped municipal government actors' perceptions of current governance network structure and changes needed to ensure BES provision, and then discussed the implications of these perceptions, highlighting opportunities and challenges for EBM implementation for beaches under conditions of change.

\section{Barrier 1: Overcome current governance structures}

Actor diversity is an important asset for EBM implementation (Bodin et al., 2017; Smythe et al., 2014), especially in beaches, due to their multiple uses (Sardá et al., 2015). The involvement of varied backgrounds increases the available pool of knowledge, experiences, and resources (Bodin et al., 2017; Carlsson \& Sandström, 2007; Smythe et al., 2014). The more diverse an environmental governance network, the more adaptability to local particularities and potential for innovative management it generates (Holzkämper, 2017). Diversity, therefore, benefits EBM implementation by improving the capacity to manage social-ecological change and uncertainty (Chapin III et al., 2009). Although the public sector was the dominant category, its lower representation on DGNs indicates that beach managers recognized the need to increase network diversity beyond the government sector. 
Civil society involvement in governance networks can increase the legitimacy of decision-making and improve governance effectiveness (Carlsson \& Sandström, 2007). Beaches support a wide range of uses, often by the private sector, which must thus be involved (Sardá et al., 2015; Williams \& Micallef, 2009). City councils can support EBM implementation by endorsing the participation of the private sector and civil society, and trigger changes at formal planning stages, for instance by promoting seminars and funding projects (Wamsler et al., 2014). Along with locally grounded, empirical knowledge, scientific knowledge is fundamental for EBM implementation (Arkema et al., 2006; McLeod \& Leslie, 2009), and must be improved in the LNP region (Simôes et al., 2017). Our Net-Map participants aimed to increase nongovernmental sector participation (e.g., civil society, research organizations) in beach management. They also perceived the private sector, council bodies, and research organizations as endowed with the high power and/or expertise needed to promote desired changes. By shifting beach governance toward desired constellations, the government may thus enable a successful EBM implementation within multi-actor comanagement.

Actor diversity is an asset to EBM implementation, but it requires a network structure that enables actors of different sectors to interact in a cohesive (i.e., with low fragmentation, see Coleman, 1990) and collaborative governance network (Bodin et al., 2017; Smythe et al., 2014). Decreased fragmentation enhances the exchange of resources (Bodin \& Crona, 2009), enabling responses to complex environmental challenges (Bodin \& Crona, 2009; Bodin et al., 2017; Smythe et al., 2014) and supporting a network's overall adaptive capacity and resilience (Bodin \& Crona, 2009). Since fragmentation is a major challenge for sustainability in marine governance (Kelly et al., 2018), the participants' desire for decreased fragmentation in their beach management networks is another opportunity for EBM implementation.

Brazil's beach management faces discontinuities in management programs and public policies due to personnel changes associated with newly elected governments, and also because procedural practices are often not formalized (Xavier et al., in press). Managers stated that "a limiting issue [for the changes in the governance network] is the discontinuation of projects. Every time a new government initiates its mandate, the ongoing projects are delayed." A decrease in network fragmentation increases the stability of the network (Carlsson \& Sandström, 2007), which might enable the managers to better deal with sudden changes in beach management and support EBM implementation.

EBM implementation requires networks that connect different sectors (Bodin et al., 2017; Sardá et al., 2015), which depends on trust and collective action (Bodin et al., 2017). Trust can be improved by social ties among actors with similar backgrounds (Bodin \& Crona, 2009; Holzkämper, 2017), such as perceived by the "homophily" types of change. However, actors who only interact within their 
own social group might experience a homogenization of assets and ideas (Bodin, 2017). "Self-organized homophily," therefore, may not include the exchange of knowledge and resources required by EBM, while the "coordinated homophily" approach envisions a central actor linking mostly homogeneous "subgroups," thereby connecting different sectors of society.

The heterophily-oriented change also supports cooperation between actors of different sectors of society. Developing cooperation between actors with different backgrounds, however, requires resources that, if absent, can hamper EBM implementation processes (Bodin et al., 2017). In our Brazilian study area, local beach managers' desire for governance with increased heterophily is challenged by a lack of resources and skills, such as lack of public participation, knowledge, and power-sharing, and difficulties in engaging stakeholders (Corrêa et al., in press; Xavier et al., in press). LNP beach management will require coordination to benefit from actor diversity. A leader with a central network position can promote interaction between different social sectors thus facilitating the collaborative governance needed for EBM implementation (Bodin et al., 2017). High levels of centralization are associated with better coordination among diverse actors (Smythe et al., 2014), which can render decision-making more efficient (Carlsson \& Sandström, 2007). The "coordinated homophily" type of network change might thus best promote knowledge exchange and coordination for EBM implementation.

Only one municipal office envisioned "coordinated homophily" as a needed network change. Reasons for this range from feasibility considerations to individual perceptions of good governance or network knowledge. At the same time, some sectors of society were not perceived at all by individual municipalities or were seen as having either no power or no expertise for governance network transformation. For example, although research organizations were perceived only as providers of information and knowledge (i.e., high expertise and low power), several cases have shown that researchers can foster the participation of other social actors in coastal management (e.g., Araça Bay, and RESEX-CT Bragança, see Glaser et al., 2020), thus improving governance (Carlsson \& Sandström, 2007). The near absence of these visions among LNP beach managers might hamper the likelihood of EBM implementation seizing the opportunities generated by the recognized need for increasing actor diversity and network interactions.

\section{Barrier 2: Fit governance with multilevel ecosystem dynamics}

Beach management occurs mostly at the local level (Williams \& Micallef, 2009), but deals with multilevel biophysical processes (McLachlan \& Defeo, 2018). Connecting managers beyond the boundaries of their municipal territories is likely to improve the management of ecosystems that cross administrative borders (Bodin, 2017). An intermunicipal collaborative network that creates horizontal 
connectivity between localities sharing the same beach systems can better account for ecosystem dynamics in EBM implementation (Christie et al., 2009; EismaOsorio et al., 2009; Wamsler et al., 2014).

Local-to-local (i.e., intermunicipal) collaboration in EBM can increase stakeholder participation and the exchange of information and resources to enhance local formal institutions, coastal law enforcement, and the implementation of new approaches (Eisma-Osorio et al., 2009). It can also foster watershed-level coordination (Wamsler et al., 2014), necessary for sustainable beach management (Sardá et al., 2015). In Brazil, intermunicipal collaboration has increased local municipalities' innovation capacity and their power to negotiate with state and federal governments (Grin, 2019). Intermunicipal collaboration would address further challenges pointed out by LNP beach managers: the perceived low expertise and relatively low power of the municipal level, and the continuation of projects and plans beyond single electoral periods. Additionally, intermunicipal collaboration is fundamental for enhancing social-ecological fit and promoting the municipalities as a regional group.

EBM implementation that links local municipalities may be motivated by three main perceptions among ecosystem managers: (1) there is a natural biophysical interdependence in ecosystem functioning (Bodin, 2017); (2) local municipalities affect each other; and (3) local municipalities share issues and resource bases (e.g., financial, infrastructure) (Eisma-Osorio et al., 2009). In the LNP region, we found no indication that managers held any of these perceptions. Net-Map participants included actors from other municipalities in neither their perceived (CPGN) nor desired (DGN) networks. Although some of their perceptions might hamper EBM implementation, municipal officers also envisioned opportunities for EBM implementation in the governance network. If municipalities are to succeed in seeing themselves as a regional group, their perceptions will be a base for overcoming the challenges for EBM implementation in the region. It seems unlikely that, without external influence, the LNP municipalities will establish an intermunicipal network to exchange and share resources such as information, knowledge, experiences, and perceptions.

Actors from higher administrative levels might be needed to horizontally connect the municipalities and promote exchange between them. Gorris (2015), for example, found low horizontal connectivity between local administrative units in large marine protected areas in both northeast Brazil and Indonesian South Sulawesi. In the Net-Maps conducted in our study, higher level actors were seen as having high power and expertise, which enabled them to promote the envisioned BES governance network. Their coordination of actors across administrative boundaries can promote a better fit between collaborative network structures and multi-level ecosystem dynamics (Bodin, 2017). Thus, coordinated actions to implement EBM locally and regionally can increase the adaptive capacity of governance (Christie et al., 2009; Österblom et al., 2010). 
The regional level is fundamental for connecting multiple system levels and scales that influence ecosystem dynamics (Glaser \& Glaeser, 2014). Regional council bodies can connect municipalities, and also connect with higher level government actors to obtain financial and technical training or education support, increase social-ecological fit, and promote political continuity for EBM implementation (Eisma-Osorio et al., 2009). In the LNP, regional council bodies already connect all municipalities, state, and federal actors from all sectors of society (Santos \& Turra, 2017). Although their decisions affect beach management, the LNP council bodies do not discuss beach management. ${ }^{6}$ This lack of focus on beaches may explain why the regional councils were not identified as BES network actors by several of the Net-Map participants. However, when identified by the participants, the regional council bodies, and some of their member organizations including regional nongovernmental organizations (NGOs), research organizations, and higher level public sector actors, were ascribed high power and expertise. This perception might foster the regional council bodies' role in integrating key actors. The LNP council bodies, in partnership with higher level authorities, regional NGOs, and research organizations, could support discussions on regional EBM-based beach management through intermunicipal, multilevel, and multi-sector collaboration.

\section{Local managers as leaders of EBM implementation}

Our Net-Map participants provided an important picture of beach management in the LNP region. All beach managers saw the need to increase diversity and collaboration in governance networks. They perceived both the local and regional levels as endowed with a high level of power, and therefore as potentially effective in promoting the transformations needed for the long-term provision of BES. These perceptions provide a point of departure to develop strategies for beach management challenges, such as discontinuity in management and public policies, lack of inclusive social participation, and the science-practice gap. In a collaborative framework, a leader ensures the effective exchange of information, resources, and knowledge and facilitates collaboration among multiple sectors (Bodin et al., 2017; Simóes et al., 2017). This study demonstrates that local government managers envision network changes that might support local EBM implementation and that they can thus be regarded as potential local leaders for such a venture.

6 As previously mentioned, this information comes from two workshops carried out with the main LNP Council bodies to discuss beach management. The workshops were held by a bigger research project that includes the present research. The data still is unpublished. 
However, given the low degree of perceived horizontal connectivity between the municipalities of the LNP region, beach managers might require a facilitator to enhance their skills and expertise and to foster their perception of themselves as a regional group. The participating beach managers' lack of shared interests or identity reduces their potential as leaders for EBM implementation. Their perceptions of BES governance improvement might undermine the fit between governance and environmental dynamics of the beaches of the study region, and hamper the horizontal, intermunicipal exchange of knowledge that is needed to seize the potentials revealed by the beach managers' perception patterns.

This study revealed the willingness of managers to better involve research organizations in the governance network, allowing for researchers to act as facilitators for beach managers to establish their leadership role. Partnerships to capacitate and empower local managers and to enhance knowledge exchange with key actors (e.g., regional council bodies) would promote long-term BES provision based on effective EBM implementation. Future perception studies might extend to other beach management stakeholders' understandings of governance and management and thus lay additional foundations for increasing stakeholder collaboration for EBM. Moreover, the link types (information, support, resources, and conflicts) between actor categories might be analyzed separately to clarify their role in EBM implementation.

Our use of Net-Map and SNA methodologies in the EBM context facilitated cooperation between researchers and managers in adapting management practices. This study demonstrates how local government managers' perceptions of the necessary improvements to the ES governance network are a critical precondition for EBM implementation. We focused on the perceptions of beach managers as primary ecosystem governance actors, a focus that can also support EBM implementation in other types of ecosystems. As humanity's impact on nature becomes ever more dominant, the focus on collaborative governance networks we develop in this study is likely to gain wider relevance. Since other contextual conditions are also critical for EBM implementation, further research is needed on public policies, institutions, usable knowledge, information basis, and innovation uptake.

\section{Acknowledgments}

This paper is part of the first author's master's thesis. The authors acknowledge the contribution of all participants in this study for sharing their knowledge. We also thank the São Paulo Research Foundation (FAPESP: MRC 2018/13238-9 and 2019/13898-1 and LYX: 2017/21797-5 and 2019/13851-5), the Brazilian National Council for Scientific and Technological Development (AT: 309697/2015-8 310553/2019-9), the Coordenação de Aperfeiçoamento de Pessoal de Nível 
Superior-Brasil (Finance Code 001), and the Programa Bolsas Funbio (Conservando o Futuro in partnership with Instituto Humanize) for their support. This work is part of the ongoing project "Environmental governance in the São Paulo macrometropolis due to climate variability" (FAPESP: 2015/03804-9), linked to the FAPESP Global Climate Change Research Program.

\section{References}

Adger, W. N. (2003). Social aspects of adaptive capacity. In J. B. Smith, R. J. T. Klein, \& S. Huq. (Eds.). Climate change, adaptive capacity, and development (pp. 29-49). Imperial College Press. doi.org/10.1142/9781860945816_0003

Amaral, A. C. Z., Corte, G. N., Filho, J. S. R., Denadai, M. R., Colling, L. A., Borzone, C., ... Almeida, T. C. M. (2016). Brazilian sandy beaches: Characteristics, ecosystem services, impacts, knowledge, and priorities. Brazilian Journal of Oceanography, 64(Spe2), 5-16. doi.org/10.1590/s1679-875920160933064sp2

Arkema, K. K., Abramson, S. C., \& Dewsbury, B. M. (2006). Marine ecosystem-based management: From characterization to implementation. Frontiers in Ecology and the Environment, 4(10), 525-532. doi.org/10.1890/1540-9295(2006)4[525:memfct]2.0.co;2

Aswani, S., Christie, P., Muthiga, N. A., Mahon, R., Primavera, J. H., Cramer, L. A., ... Hacker, S. (2012). The way forward with ecosystem-based management in tropical contexts: Reconciling with existing management systems. Marine Policy, 36(1), 1-10. doi.org/10.1016/j.marpol.2011.02.014

Beyerl, K., Putz, O., \& Breckwoldt, A. (2016). The role of perceptions for communitybased marine resource management. Frontiers in Marine Science, 3, Article 238. doi.org/ 10.3389/fmars.2016.00238

Biermann, F., Betsill, M. M., Gupta, J., Kanie, N., Lebel, L., Liverman, D., ... Zondervan, R. (2010). Earth system governance: A research framework. International Environmental Agreements: Politics, Law, and Economics, 10(4), 277-298. doi.org/10.1007/s10784-0109137-3

Bodin, Ö. (2017). Collaborative environmental governance: Achieving collective action in social-ecological systems. Science, 357(6352), Article 1114. doi.org/10.1126/science. aan 1114

Bodin, Ö., \& Crona, B. I. (2009). The role of social networks in natural resource governance: What relational patterns make a difference? Global Environmental Change, 19(3), 366374. doi.org/10.1016/j.gloenvcha.2009.05.002

Bodin, Ö., Sandström, A., \& Crona, B. (2017). Collaborative networks for effective ecosystem-based management: A set of working hypotheses. Policy Studies Journal, 45(2), 289-314. doi.org/10.1111/psj.12146 
Borgatti, S. P., Everett, M. G., \& Freeman, L. (2002). UCINET for Windows (Version 6.535) [Computer software]. Analytic Technologies. sites.google.com/site/ucinetsoftware/home

Carlsson, L., \& Sandström, A. (2007). Network governance of the commons. International Journal of the Commons, 2(1), 33-54. doi.org/10.18352/ijc.20

Chapin III, F. S., Kofinas, G. P., \& Folke, C. (Eds.). (2009). Principles of ecosystem stewardship: Resilience-based natural resource management in a changing world. Springer. doi.org/ 10.1007/978-0-387-73033-2

Christie, P., Pollnac, R. B., Oracion, E. G., Sabonsolin, A., Diaz, R., \& Pietri, D. (2009). Back to basics: An empirical study demonstrating the importance of local-level dynamics for the success of tropical marine ecosystem-based management. Coastal Management, 37(3-4), 349-373. doi.org/10.1080/08920750902851740

Cohen, P. J., Evans, L. S., \& Mills, M. (2012). Social networks supporting governance of coastal ecosystems in Solomon Islands. Conservation Letters, 5(5), 376-386. doi.org/ $10.1111 /$ j.1755-263x.2012.00255.x

Coleman, J. S. (1990). Foundations of social theory. Harvard University Press.

Corrêa, M. R., Xavier, L. Y., Gonçalves, L. R., Andrade, M. M., Oliveira, M., Malinconico, N., ... Turra, A. (in press). Desafios para promoção da abordagem ecossistêmica à gestão de praias na América Latina e Caribe (Challenges for promoting the ecosystem approach to beach management in Latin America and the Caribbean). Revista Estudos Avançados (Advanced Studies Magazine).

Eisma-Osorio, R. L., Amolo, R. C., Maypa, A. P., White, A. T., \& Christie, P. (2009). Scaling up local government initiatives toward ecosystem-based fisheries management in Southeast Cebu Island, Philippines. Coastal Management, 37(3-4), 291-307. doi.org/ $10.1080 / 08920750902851237$

Freeman, L. (2004). The development of social network analysis: A study in the sociology of science. Empirical Press.

Glaser, M., Barboza, R. S. L., Borges, R., Blandtt, L., Gerhardinger, L. C., Ferreira, B. P., ... Turra, A. (2020). Trajectory of social participation in Brazillian coastal and ocean management. In B. Glaeser \& M. Glaser (Eds.), Coastal management revisited: Towards sustainable human-nature relations. Elsevier.

Glaser, M., \& Glaeser, B. (2014). Towards a framework for cross-scale and multi-level analysis of coastal and marine social-ecological systems dynamics. Regional Environmental Change, 14, 2039-2052. doi.org/10.1007/s10113-014-0637-5

Glaser, M., Gorris, P., Ferreira, B. P., \& Breckwoldt, A. (2018). Analysing ecosystem user perceptions of the governance interactions surrounding a Brazilian near-shore coral reef. Sustainability, 10(5), Article 1464. doi.org/10.3390/su10051464 
Gorris, P. (2015). Entangled? Linking governance systems for regional-scale coral reef management: Analysis of case studies in Brazil and Indonesia [Doctoral dissertation, Jacob University, Leibniz Centre for Tropical Marine Research]. nbn-resolving.org/urn:nbn:de:gbv:579opus-1002112

Granek, E. F., Polasky, S., Kappel, C. V., Reed, D. J., Stoms, D. M., Koch, E. W., ... Wolanski, E. (2010). Ecosystem services as a common language for coastal ecosystembased management. Conservation Biology, 24(1), 207-216. doi.org/10.1111/j.1523-1739. 2009.01355.x

Grin, E. J. (2019). Federalismo, governança e cooperação intermunicipal no Brasil: um balanço da literatura (Federalism, governance and intermunicipal cooperation in Brazil: A review of the literature). In J. M. B. Carneiro \& E. S. Brito (Eds.) Consórcios Intermunicipais e Politicas Públicas Regionais (Intermunicipal consortia and regional public policies) (pp. 37-54). Oficina Municipal Brasiliense.

Grothmann, T., \& Patt, A. (2005). Adaptive capacity and human cognition: The process of individual adaptation to climate change. Global Environmental Change, 15(3), 199-213. doi.org/10.1016/j.gloenvcha.2005.01.002

Holzkämper, E. M. (2017). Comparing realities: Analysis of stakeholders' perceptions relating to the governance network of a MPA - the case of the Coral Coast Environmental Protection Area, Brazil [Unpublished Master of Science thesis]. University of Bremen, Leibniz Centre for Tropical Marine Research.

Imperial, M. T. (1999). Institutional analysis and ecosystem-based management: The institutional analysis and development framework. Environmental Management, 24(4), 449-465. doi.org/10.1007/s002679900246

Kelly, C., Ellis, G., \& Flannery, W. (2018). Conceptualising change in marine governance: Learning from transition management. Marine Policy, 95, 24-35. doi.org/10.1016/ j.marpol.2018.06.023

Kirkfeldt, T. S. (2019). An ocean of concepts: Why choosing between ecosystem-based management, ecosystem-based approach and ecosystem approach makes a difference. Marine Policy, 106, Article103541. doi.org/10.1016/j.marpol.2019.103541

Leslie, H., Sievanen, L., Crawford, T. G., Gruby, R., Villanueva-Aznar, H. C., \& Campbell, L. M. (2015). Learning from ecosystem-based management in practice. Coastal Management, 43(5), 471-497. doi.org/10.1080/08920753.2015.1051424

McLachlan, A., \& Defeo, O. (2018). The ecology of sandy shores (3rd ed.). Academic Press. doi.org/10.1016/B978-0-12-809467-9.12001-6

McLeod, K. L., \& Leslie, M. (Eds.). (2009). Ecosystem-based management for the oceans. Island Press. 
Ministério do Meio Ambiente (Ministry for the Environment). (2018). Portaria no 76, de 26 de março de 2018: Institui o Programa Nacional para Conservação da Linha de Costa (Ordinance no. 76, March 26, 2018: Institutes the National Program for Coastline Conservation). Diário Oficial da União (Official Gazette of the Union)_DF, 28 Mar, $\mathrm{n}^{\circ}$ 60, section 1, p. 161. www.ibama.gov.br/sophia/cnia/legislacao/MMA/PT0076-26 0318.pdf

Moser, S. C., \& Tribbia, J. (2006). Vulnerability to inundation and climate change impacts in California: Coastal managers' attitudes and perceptions. Marine Technology Society, 40(3), 4-13. doi.org/10.4031/002533206787353169

O’Higgins, T. G., Lago, M., \& Dewitt, T. H. (2020). Ecosystem-based management, ecosystem services and aquatic biodiversity: Theory, tools and applications. Springer. doi. org/10.1007/978-3-030-45843-0

Österblom, H., Gårdmark, A., Bergström, L., Müller-Karulis, B., Folke, C., Lindegren, M., ... Möllmann, C. (2010). Making the ecosystem approach operational—can regime shifts in ecological- and governance systems facilitate the transition? Marine Policy, 34(6), 1290-1299. doi.org/10.1016/j.marpol.2010.05.007

Sandström, A., Bodin, Ö., \& Crona, B. (2015). Network governance from the top-the case of ecosystem-based coastal and marine management. Marine Policy, 55, 57-63. doi. org/10.1016/j.marpol.2015.01.009

Santos, C., \& Turra, A. (Eds.). (2017). Rumos da sustentabilidade costeira: visão do Litoral Norte Paulista (Pathways towards coastal sustainability: Investigating the North Coast of São Paulo State). Universidade São Paulo Instituto Oceanográfico.

Sardá, R., \& Azcárate, J. P. (2018). A decision making (DEMA) tool to be used in ecosystembased management system (EBMS) applications. In C. M. Botero, O. Cervantes, \& C. W. Finkl (Eds.), Coastal research library: Vol. 24. Beach management tools-concepts, methodologies and case studies (pp. 21-24). Springer. doi.org/10.1007/978-3-319-583044_2

Sardá, R., Valls, J. F., Pintó, J., Ariza, E., Lozoya, J. P., Grafuell, R. M., ... Jimenez, J. A. (2015). Towards a new integrated beach management system: The ecosystem-based management system for beaches. Ocean \& Coastal Management, 118(Part B), 167-177. doi.org/10.1016/j.ocecoaman.2015.07.020

Scherer, M. E. G., Nicolodi, J. L., Costa, M. F., Corriani, N. R., Gonçalves, R. K., Cristiano, S. C., ... Pfuetzenreuter, A. (2020). Under new management. Journal of Coastal Research, 95(sp1), 945-952. doi.org/10.2112/si95-184.1

Schiffer, E., \& Hauck, J. (2010). Net-Map: Collecting social network data and facilitating network learning through participatory influence network mapping. Field Methods, 22(3), 231-249. doi.org/10.1177/1525822x10374798

Simóes, E., Junior, W. C., Freitas, D. M., Mills, M., Iwama, A. Y. Gonçalves, I., Olivato, D., \& Fidelman, P. (2017). Barriers and opportunities for adapting to climate change on the North Coast of São Paulo, Brazil. Regional Environmental Change, 17, 1739-1750. doi. org/10.1007/s10113-017-1133-5 
Smythe, T. C., Thompson, R., \& Garcia-Quijano, C. (2014). The inner workings of collaboration in marine ecosystem-based management: A social network analysis approach. Marine Policy, 50(Part A), 117-125. doi.org/10.1016/j.marpol.2014.05.002

Sørensen, E., \& Torfing, J. (2016). Political leadership in the age of interactive governance: Reflections on the political aspects of metagovernance. In J. Edelenbos \& I. Meerkerk. (Eds.). Critical reflections on interactive governance (pp. 444-466). Edward Elgar Publishing. doi.org/10.4337/9781783479078.00026

Tallis, H., Levin, P. S., Ruckelshaus, M., Lester, S. E., McLeod, K. L., Fluharty, D. L., \& Halpern, B. S. (2010). The many faces of ecosystem-based management: Making the process work today in real places. Marine Policy, 34(2), 340-334. doi.org/10.1016/ j.marpol.2009.08.003

Wamsler, C., Luederitz, C., \& Brink, E. (2014). Local levers for change: Mainstreaming ecosystem-based adaptation into municipal planning to foster sustainability transitions. Global Environmental Change, 29, 189-201 doi.org/10.1016/j.gloenvcha.2014.09.008

Williams, A. T., \& Micallef, A. (2009). Beach management: Principles and practice. Earthscan.

Xavier, L. Y., Gonçalves, L. R., De Oliveira, M., Corrêa, M. R., Malinconico, N., Polette, M., \& Turra, A. (in press). Beach management and conservation in Brazil. In C. Z. Amaral, G. N. Corte, \& H. H. Checon (Eds.). Brazilian sandy beaches. Springer.

\section{Appendix I}

\section{Determining Net-Map participants}

Beach managers are government officers concerned with civil society safety, environmental protection, public structure, and the development of coastal areas close to beaches (Moser and Tribbia, 2006). In Brazil, the beach managers can be permanent public officers, who hold their public sector positions when political mandates change, carrying knowledge and experience about the organization functioning, and technical knowledge, across changes in governance. As part of a technical team, beach managers often provide important knowledge to guide decision-making. Beach managers can also be temporary officers who work during a single electoral mandate and, as municipal officers, are responsible for final decision-making in that period. These nonpermanent municipal officers can also be part of the technical team but are usually more involved with political decisionmaking. For this research, we set up Net-Map sessions with the municipal officer and with at least two permanent members of the technical teams working in the selected municipal offices of the LNP municipalities. 
In order to develop a list of selection criteria, we reviewed municipal policies concerning the administrative structure and competencies of the municipal offices in the four municipal governments in the LNP region (Ilhabela, Caraguatatuba, São Sebastiâo, and Ubatuba), matching relevant terms with those used in the formulation of policies. This review resulted in the following list of nine terms related to beach management: (1) vulnerability reduction, (2) monitoring, (3) disaster prevention, (4) sustainability, (5) planning, (6) integration of sectors, (7) beaches, (8) climate change, and (9) erosion. We compared these nine terms with the mandates of all government offices in the LNP region and selected those offices where mandates matched the selection criteria. Additionally, we reviewed national public policies associated with the terms "beach," "shoreline," and "climate change." We identified the municipal government actors quoted in these policies and thus were able to cross-check our selection of municipal offices and obtain data on which municipal governmental bodies are formally responsible for beach management in the LNP region. Of the 12 offices contacted, 11 responded. Table A1 presents an overview of the 11 offices (and their tasks) selected for conducting Net-Map sessions.

Table A1. List of municipal government offices associated with beach management that attended the group interviews.

\begin{tabular}{|c|c|c|c|}
\hline Municipality & $\begin{array}{l}\text { Municipal } \\
\text { office* }^{*}\end{array}$ & Municipal office's official tasks & Code \\
\hline \multirow[t]{2}{*}{ Ilhabela } & $\begin{array}{l}\text { Civil Defense } \\
\text { Office }\end{array}$ & $\begin{array}{l}\text { Plan, coordinate, and execute activities and studies to } \\
\text { prevent conditions of vulnerability and threats caused } \\
\text { by situations of public calamities and disasters that } \\
\text { put people's lives and well-being at risk. }\end{array}$ & 11 \\
\hline & $\begin{array}{l}\text { Urban Planning, } \\
\text { Public Works, } \\
\text { and Housing } \\
\text { Development }\end{array}$ & $\begin{array}{l}\text { Formulate, execute, and evaluate the Municipal } \\
\text { Policy for Urban Development and Housing. Among } \\
\text { other assignments, this office aims to understand } \\
\text { and prevent the impacts of urban growth on the } \\
\text { environment as well as to identify and promote } \\
\text { opportunities for sustainable urban development } \\
\text { in the municipality. }\end{array}$ & 12 \\
\hline \multirow[t]{3}{*}{ Ubatuba } & $\begin{array}{l}\text { Civil Defense } \\
\text { Office }\end{array}$ & $\begin{array}{l}\text { Communicate and coordinate studies to track } \\
\text { situations of risk for the population's well-being } \\
\text { (e.g., natural disasters), as well as develop action } \\
\text { plans to deal with risks. }\end{array}$ & U1 \\
\hline & $\begin{array}{l}\text { Urban planning } \\
\text { Office }\end{array}$ & $\begin{array}{l}\text { Formulate, execute, and evaluate the Municipal } \\
\text { Policy for Urban Development and urbanization } \\
\text { projects. Among other assignments, this office aims } \\
\text { to understand and prevent the impacts of urban } \\
\text { growth on the environment. It also aims to ensure the } \\
\text { regulation of areas that belong to federal entities. }\end{array}$ & U2 \\
\hline & $\begin{array}{l}\text { Environment } \\
\text { Office }\end{array}$ & $\begin{array}{l}\text { Organize, plan, and guide the municipality's } \\
\text { environmental policy. This office attends to the } \\
\text { environmental demands of the city. In partnership with } \\
\text { the Urban Planning Office and other offices, this office } \\
\text { aims to ensure the protection, conservation, and } \\
\text { recovery of the environment, as well as to promote } \\
\text { sustainable actions in the municipality. }\end{array}$ & U3 \\
\hline
\end{tabular}




\begin{tabular}{|c|c|c|c|}
\hline Municipality & $\begin{array}{l}\text { Municipal } \\
\text { office* }\end{array}$ & Municipal office's official tasks & Code \\
\hline \multirow[t]{3}{*}{ São Sebastião } & $\begin{array}{l}\text { Civil Defense } \\
\text { Office }\end{array}$ & $\begin{array}{l}\text { Assess and prevent disasters, vulnerabilities, } \\
\text { and risks to which the municipality is subjected. } \\
\text { This office is responsible for planning institutional } \\
\text { activities, providing human resources (training } \\
\text { courses), developing scientific/technological studies, } \\
\text { mobilizing, monitoring, and alerting the municipality, } \\
\text { and providing logistical support following disasters. }\end{array}$ & SS1 \\
\hline & $\begin{array}{l}\text { Beach } \\
\text { Management } \\
\text { Office }\end{array}$ & Not specified in the legislation. & SS2 \\
\hline & $\begin{array}{l}\text { Environment } \\
\text { Office }\end{array}$ & $\begin{array}{l}\text { Develop studies, actions, and activities related } \\
\text { to the protection, conservation, and recovery of } \\
\text { the environment. This office is responsible for } \\
\text { including all sectors of the society and the different } \\
\text { municipal offices in the promotion of environmentally } \\
\text { sustainable actions in the municipality. }\end{array}$ & SS3 \\
\hline \multirow[t]{3}{*}{ Caraguatatuba } & $\begin{array}{l}\text { Civil Defense } \\
\text { Office }\end{array}$ & $\begin{array}{l}\text { Develop and implement policies and plans that } \\
\text { promote the protection of the citizens' well-being } \\
\text { against disasters. This office unifies and integrates } \\
\text { government agencies and society, aiming to organize } \\
\text { and expand the adaptive capacity of the municipality } \\
\text { to prevent and address environmental risks within it. }\end{array}$ & C1 \\
\hline & $\begin{array}{l}\text { Urban Planning } \\
\text { Office }\end{array}$ & $\begin{array}{l}\text { Develop, study, and revitalize municipal urban } \\
\text { planning, legislation, and projects, ensuring the } \\
\text { preservation of the natural environment and } \\
\text { population well-being. }\end{array}$ & $\mathrm{C} 2$ \\
\hline & $\begin{array}{l}\text { Fisheries, } \\
\text { Aquaculture and } \\
\text { Environment } \\
\text { Office }\end{array}$ & $\begin{array}{l}\text { Promote the integration of municipal offices, citizens, } \\
\text { research institutions, state and union actions, } \\
\text { and knowledge with respect to the planning of } \\
\text { use, conservation, recovery, and protection of the } \\
\text { environment. Among other assignments, this office } \\
\text { is responsible for advising and offering training } \\
\text { about the environment and its sustainable use, with } \\
\text { a holistic, scientific, and participatory approach } \\
\text { that considers the interdependence of the natural, } \\
\text { socioeconomic, and cultural environments. }\end{array}$ & C3 \\
\hline
\end{tabular}

* Denominations of offices translated to English by authors.

Source: Authors' summary.

\section{Appendix II}

\section{Data treatment}

1. Actors were grouped to generate a simplified overview of all the networks. For example, divisions within the Environmental State Office were grouped as "Environmental State Office." 
2. Relations (links) were classified as either "collaborative relations" or "conflict relations," thus allowing for the construction of two coexisting networks: the "governance collaboration network" and the "governance conflict network."

3. To represent participants' assessment that some relations "need improvement," two procedures were adopted:

- existing "collaborative relations" (in CPGN) that were marked as "need improvement" (in DGN) received a weight of 1 in CPGN, while all other relations were weighted as 2 (indicating a stronger link);

- existing "conflict relations" (in CPGN) that were marked as "need improvement" (in DGN) were disregarded in collaborative CPGN (only positive links were represented) and considered in DGN as "new" positive links. 
This text is taken from Human Ecology Review, Volume 26, Number 2, 2020, published by ANU Press, The Australian National University, Canberra, Australia. doi.org/10.22459/HER.26.02.2020.04 